\title{
O Discurso Sobre O Amor No Banquete, De Platão, E A Presença De Diotima De Mantineia: MULHER/SACERDOTISA/HETAIRA
}

\author{
Yvisson Gomes dos Santos ${ }^{1}$ \\ Walter Matias Lima ${ }^{2}$
}

\section{RESUMO}

O presente artigo versa sobre o discurso de Diotima de Mantineia no Banquete, de Platão (2016). Foi utilizada a fala da sacerdotisa e hetaira (prostituta) através da alocução de Sócrates para tratar sobre o Amor como entidade demiúrgica. Na dialética platônica observamos que o Eros é um intermediário entre os homens e os deuses: filho nascido de uma mãe pobre e de um pai com recursos. A questão hipotética levantada através do texto/tecido do aristocrata Platão foi a entrada, mesmo que em instância discursiva, de uma mulher, em recinto masculino, para fazer encômio ao Amor no diálogo platônico. É de nota que Diotima de Mantineia era uma sacerdotisa e hetaira (cortesã), e que, por esse motivo, sua presença era tolerada entre os convivas do Banquete, mesmo que, repetindo: em domínio eminentemente da discursividade. Concluímos que a presença de Diotima de Mantineia trouxe ao enredo filosófico do Banquete a oportunidade de reafirmar a metafisica platônica das Formas (mundo das Ideias) e da experiência (mundo sensível) que afetam a formação do ser filósofo, este, por sua vez, devedor da Episteme nascida da Doxa para ser um amante autêntico da sabedoria.

PALAVRAS-CHAVE: Banquete; Diotima de Mantineia; Hetaira; Eros.

1 Doutorando em Educação pelo PPGE/UFAL. Mestre em educação pela Universidade Federal de Alagoas. Graduado em Filosofia. E-mail: yvissongomes@hotmail.com .

2 Possui graduação em Filosofia pela Universidade Federal de Pernambuco (1988), Mestrado em Filosofia pela Universidade Federal de Pernambuco (1995) e Doutorado em Educação (Filosofia e Educação) pela Universidade Estadual de Campinas (2003). Fez Estágio Pós-Doutorado na Université Rennes II: Centre de recherche sur l'éducation, les apprentissages et la didactique (CREAD). Professor Associado da Universidade Federal de Alagoas, no Centro de Educação. Email:waltermatias@gmail.com 


\section{INTRODUÇÃO}

Colocar a Filosofia Ocidental como nascida das mãos teóricas da Paideia (Educação) helênica é um fato que nos marca profundamente. Quando se fala de fato, reporta-se a acuidade da Grécia de Péricles ou de Sólon em seu auge cultural, político, econômico e de amizade ao saber, em meados do $V$ século a.C, que ainda nos demarca na condição de seres civilizados.

Observa-se que, no mediterrâneo grego, em tribos jônicas e dóricas, a civilização helênica foi formada e tomou firmeza em sentido forte da palavra (solidez, consistência, estabilidade), trazendo à tona vestígios sobre as quais hoje, nós ocidentais do século XXI, ainda nos debruçamos, a saber: a episteme (ciência) nascida da doxa (opinião) perfazendo elementos conceituais afinados aos silogismos lógicos, à retórica, à argumentação, ao nascimento de uma metafísica oriunda dos gregos pré-socráticos que, por sua vez, caracterizou a Filosofia de Platão de modo acintoso. Segundo Evilázio Teixeira: "o pensamento de Platão foi influenciado basicamente por quatro pensadores: Pitágoras (órfico-pitagórico), Parmênides, Heráclito e Sócrates. Mas, sobretudo, Pitágoras e Sócrates irão determinar as grandes linhas de sua filosofia" (TEIXEIRA, 2015, p. 22).

Os pensadores acima citados propuseram ao "homem de ombros largos" e de origem aristocrática a teoria da metempsicose, ou da reencarnação da alma, na linhagem pitagórica; a mutabilidade das coisas e dos devires heraclitianos; a mudança ilusória da imutabilidade nas ilações de Parmênides; e, por fim, a consciência antropológica e a discursividade socrática pelos vieses de problemas éticos (TEIXEIRA, 2015).

O aristocrata Platão, nascido em Atenas - considerada uma Cidade-Estado das mais pujantes - se aproximou de Sócrates e o teve como mestre e preceptor. Reza a tradição que "quando Platão conheceu Sócrates [...], rasgou ele seus primeiros ensaios de poesia ditirâmbica e trágica. $O$ que a seguir escreveu não foram mais poemas, mas as próprias conversas do mestre" (SOUZA, 2016, p. 192-193).

Essa ruptura com seus textos trágicos ditirâmbicos, tendo feito imersão nos diálogos de seu mestre Sócrates, arrimou a filosofia platônica como devedora do discurso socrático. Segundo Platão (1999), Sócrates foi o homem mais sábio de seu tempo, de acordo com o oráculo de Delfos, preconizando o parto das ideias em seus 
discípulos. Sócrates foi acusado de corromper a juventude e negar a existências dos deuses, sendo morto por esses crimes.

Uma acusação que terá direito de resposta retratada na Apologia de Sócrates $\left(1999^{3}\right)$, um texto filosófico e literário, em que o lugar da ironia faz assento e é seguido de locuções ideativas que colocaram Sócrates como "réu por haver-se ocupado de assuntos que não eram de sua alçada, investigando o que existe embaixo da terra e no céu, procurando transformar a mentira em verdade e ensinando-a as pessoas" (PLATÃO, 1999. 69f). O preceptor de Platão foi condenado à morte, mesmo com uma inflamada e impetuosa defesa.

Graças a seu mestre, Platão escreveu diversos diálogos que permeavam questões sobre problemáticas éticas: a Política, o Bem, a Verdade, a Amizade, o Belo, o Amor, dentre outros. Este último, o Amor, teve diversos desdobramentos teóricos, tendo sido O Banquete (2016) ou Sympósion o mais representativo e com um espírito filosófico de grande proporção.

Trata-se do louvor ao Deus Eros, tendo os convivas se encontrado na casa de Agatão que havia escrito uma peça trágica e sido vencedor do concurso de Leneias (NUNES, 2005). Na casa do poeta trágico a presença eminentemente masculina dos convidados era notória, à exceção das criadas que serviam o vinho, e de algumas dançarinas. Nesse nicho de confraternização, os homens estavam presentes em supremacia. Estamos falando de uma civilização que igualava escravos-mulheresestrangeiros-crianças no mesmo patamar. Atualmente, os termos seriam os seguintes: uma Cidade-Estado que era escravocrata, xenófoba e misógina.

Entretanto, algo de notório no livro $O$ Banquete nos chama a atenção, e será discutido no transcorrer deste artigo: a rememoração da fala de uma sacerdotisa/hetaira/estrangeira, que Sócrates coloca como força motriz para se pensar a figura poética de Eros (amor).

O discurso de uma mulher nas palavras do filósofo: "ela que me instruía nas questões de amor" (PLATÃO, 2016, 115c), atreve-nos a uma pergunta: a sociedade helênica relegava ao oîkos (privado) a mulheres comuns e, por qual motivo, Platão, através do pai da maiêutica colocou uma voz feminina em seu elogio filosófico ao Eros, no Banquete. Trata-se de Diotima de Mantineia, uma sacerdotisa e hetaira que

${ }^{3}$ PLATÃO. Apologia de Sócrates. Tradução de Maura Iglesias. São Paulo: Nova Cultural, 1999. 
havia livrado Atenas da peste na época da guerra do Peloponeso, pois "foi ela que uma vez, porque os atenienses ofereceram sacrifícios para conjurar a peste, fez por dez anos recuar a doença" (PLATÃO, 2016, 115a).

Esta primeira pergunta nos desperta outras: que papel filosófico desempenhou Diotima de Mantineia na inscrição socrática sobre o tema do Amor? E qual o lócus da mulher dentro da sociedade grega?

Nossa hipótese é que sendo Diotima uma sacerdotisa, ela poderia entrar em recinto de hegemonia masculina sem feri-lo, sendo aceita como persona mui grata pelo motivo de ser uma prostituta/sacerdotisa e não uma mulher do oîkos. Ou: Se Diotima tivesse sido uma sacerdotisa/prostituta, então ela era tolerada sem reservas em recintos eminentemente masculinos no âmbito da textualidade proposta por Sócrates no diálogo platônico.

\section{Do Óıkos Ao Público: A Mulher Na Sociedade Grega Na Época De Platão}

Estamos em um momento histórico, na época de Platão, quando florescia a democracia como prática/discurso inerente ao cidadão da polis ( $\mathrm{V}$ século a. $\mathrm{C}$ ). Quando se fala de cidadão é necessário pontuar que se trata dos seres da polis ou dos politikos. Todas as questões que envolviam os espaços públicos da CidadeEstado de Atenas eram discutidas entre os atenienses legítimos. Muitos se sobressaíam na argumentação de como ter uma cidade ordeira e justa, dentre os quais estava Sócrates que promovia debates em torno desses temas entre seus alunos/discípulos, na Ágora (praça).

A praça como formadora de uma pedagogia ou de uma Paideia iluminava as discussões acirradas sobre as práticas de punição e deveres dos cidadãos da polis. Questões nevrálgicas tais como o julgamento de Sócrates bem como as práticas sexuais ilícitas com escravos ou estrangeiros etc. - eram tratadas na esfera do espaço público.

É importante distinguirmos o público e o privado na Grécia antiga. Para isso, recorremos a M. Florenzano: 
Oîkos e pólis são dois termos gregos que indicam instituições que, pelo menos na documentação textual e no nível da História das ideias, dos valores, podem traduzir o que queremos dizer com privado e público. São termos que dificilmente podemos verter para as línguas modernas, pois sua conceituação envolve uma série de elementos característicos e específicos da sociedade grega. Grosso modo, oîkos é casa e pólis é cidade, mas 'casa' e 'cidade' empobrecem o conceito tanto de oîkos quanto de pólis (FLORENZANO, 2001, p.01).

Podemos dizer que, por mais que seja difícil uma alusão à tradução do grego para a língua portuguesa, o entendimento ou seu significado aponta uma visão antagônica: público vem da polis = dos politikos; e oîkos, do privado, da casa, do lar. Numa outra tentativa de definição sobre o termo politikos, ele "vem do grego polites; 1. 'cidadão', 2. 'polis', 3.'cidade"' (LAROUSSE, 1992, p. 547). Ou seja, a CidadeEstado grega era regida pelos cidadãos nascidos em solo ateniense, detendo esses cidadãos o direito de fala e de julgo.

No Dicionário Etimológico On-line, temos outra definição: "numa sociedade como a grega, em que a vida pública interessava a todos os cidadãos, os politikos eram aqueles que se dedicavam ao governo da polis ('a cidade' ou 'o Estado'), colocando o bem comum acima de seus interesses individuais" ([s.d], verbete $\mathrm{P})^{4}$.

Já entendido o sentido de polis, o privado era endereçado também às mulheres casadas com cidadãos gregos legítimos. Deve-se frisar que havia outras cidadesestados como Esparta, mas suas idiossincrasias civis eram completamente diferentes das de Atenas, principalmente no tocante à posição da mulher. E mais:

No nível abstrato, as mulheres constituíam o elemento central na continuidade da pólis. [...] No nível concreto, essas prioridades culturais forçavam a comunidade a ter certeza que o processo de garantia [da manutenção da hierarquia social e econômica] estava absolutamente seguro [...] (BOUVRIE apud CAMPOS, 2015, p. 14).

Em Atenas, regida por uma deusa filha de Zeus e Hera, o privado representava algo inerente aos mistérios da mulher, não somente a ela, pois o oîkos:

${ }^{4}$ DICIONÁRIO ETIMOLÓGICO. [s.d.]. Verbete P. <https://www.dicionarioetimologico.com.br/politico/> Acesso em março de 2019. 
Era um espaço fechado e funcional muito mais que ostentatório ou de aparências como 0 espaço público muitas vezes se tornava. 0 relacionamento estabelecido no interior do oîkos era pessoal, íntimo, hierárquico e desigual: marido/esposa; pai/filho; proprietário/escravo. Também a divisão do trabalho era marcada no interior do oîkos já que cada qual tinha a sua incumbência de sorte a fazer funcionar esta célula de produção: as mulheres fiavam, os homens cuidavam do gado e das terras, e assim por diante (FLORENZANO, 2001, p. 05).

Esse espaço chamado de oîkos representava a privacidade de uma casa, de um espaço fechado e das intimidades entre esposa/marido pai/filho e de escravos com seus donos. Esse território não tinha importância igual ao público - espaço privilegiado dos atenienses livres. Ou em outras palavras:

Enquanto o homem ocupava todos os espaços externos, participava ativamente da vida política e gozava de grande liberdade, as mulheres permaneciam no interior da casa, desempenhando o papel social que lhes fora designado: o de esposas e o de mães (CAMPOS, 2015, p. 12).

Era somente imputada à mulher o papel social de estar no oîkos: mulheres esposas de homens livres. Temos a figura de Xantipa, companheira de Sócrates, que foi caricaturada e ridicularizada como mulher inconveniente, arredia, impulsiva e desafiadora de seu esposo. Esse modelo preestabelecido denotava o perfil do patriarcado grego em colocar a mulher (gynaíka) em submissão. Platão nos diz: "Se a natureza não tivesse criado as mulheres e os escravos teria dado ao tear a propriedade de fiar sozinho" (PLATÃO, 1964, p. 135). Segundo Nadia Lima, o "homem-livre era sinônimo de homem, macho da espécie humana (e não de mulher), de ateniense (e não de estrangeiro) e de cidadão (e não de escravo)" (LIMA, [s.d], p. 18).

Mas seria a mulher ateniense somente colocada nesse papel de submissão ao Oîkos? Respondemos que não, pois havia outras mulheres que detinham o saber, a escrita, a participação invejável na política e que estavam juntas dos atenienses de forma quase idêntica e/ou tolerada. Falamos das Hetairas (prostitutas) ou das sacerdotisas.

Segundo Nickie Roberts (1998), as filhas de Afrodite cortesã eram inúmeras, tanto as que estavam subordinadas a mulheres proxenetas, quanto aquelas que eram sacerdotisas e hetairas. Essas últimas galgavam poderes econômicos, filosóficos e espirituais entre os homens de Atenas - não se colocavam em submissão e nem se apartavam do cuidado de si mesmas - saíam em praça pública com vestidos coloridos 
ou brancos com fitas vermelhas, mostrando-se privilegiadas entre os politikos. Roberts aponta:

As Hetairae conduziam seus negócios abertamente em Atenas, trabalhando independentemente tanto dos bordéis do Estado quanto dos templos [...]. Cada cortesã tinha uma pedra que ela usava para registar mensagens, e toda manhã um cliente lhe escrevia cumprimentos, justamente com os detalhes mais práticos, como o horário sugerido e o preço. $\mathrm{O}$ escravo pessoal da prostituta levava a mensagem para a sua senhora e, se os termos fossem do seu agrado, a cortesã se dispunha a encontrar com o cliente mais tarde [...] Ao anoitecer, o jardim estava repleto de belas mulheres e seus clientes, flertando, se divertindo, negociando (ROBERTS, 1988, p.41).

Podemos perceber que entre as hetairas, fruto da deusa Afrodite, sua liberdade era própria por serem consideradas sagradas. Podiam ter escravo e negociar com seus clientes da forma que Ihes aprouvesse. Temos também as seguidoras de Safo, de Lesbos, que eram iniciadas da ordem do amor e nas práticas sáficas. Elas, tal como as Hetairas, tinham um grau de instrução elevado, e "envolviam-se em encontros apenas do seu próprio sexo: banquetes e festivais frequentados apenas por mulheres, em que as participantes tanto homenageavam sua deusa, Afrodite, quanto celebravam sua convocação" (ROBERTS, 1988, p. 51).

A figura de Diotima de Mantineia representava tanto a sacerdotisa, quando a hetaira. Como podemos afirmar isto? Segundo Shannon Bell (apud MARDONES, 2010, p. 24):

El mismo nombre de 'Diotima' es un indicio del templo de la prostituta o sacerdotisa. 'Diotima' significa quien le rinde honores a Dios', alguien quien trabaja al servicio del dios o de las diosas [...] Hay una evidencia textual y contextual para señalar a Diotima como hetaira [...]. En Diotima, la construcción de Eros combina de similar manera lo sexual y reproductivo, y como a prostituta sagrada él media entre los dioses y los seres humanos. El Eros de Diotima es 'un espíritu muy poderoso', un daimon, 'a mitad de camino entre dios y los seres humanos' (MARDONES, 2010, p. 24).5

E continua o texto:

\footnotetext{
5 "O verdadeiro nome 'Diotima' é um traço para a prostituta do templo ou sacerdotisa; 'Diotima' significa aquela que honra a Deus, aquela que trabalha ao serviço do deus ou da deusa [...] Há uma evidência textual e contextual para marcar Diotima a hetaira [...] Na construção de Diotima, Eros combina de forma semelhante o sexual e o reprodutivo e, como a prostituta sagrada, ele medeia entre os deuses e o homem. O Eros de Diotima é 'um espírito muito poderoso', um daimon, 'a meio caminho entre Deus e o homem"' (Tradução livre).
} 
La prostituta sagrada era en un sentido la manifestación humana de Eros: el cuerpo real a través del cual el ser humano podía copular con los dioses. Eros, como la hetaerae, era una 'experta en brujería, encantamiento y seducción' (2010, p. 24)6.

Ora, já podemos observar que a sacerdotisa/hetaira Diotima de Mantineia lidava com os códices do Eros, um demiurgo ${ }^{7}$, quando se expressava na boca de Sócrates, no Banquete, através da metáfora da origem do amor.

Prestemos atenção que ela era adepta da feitiçaria, do amor, do encantamento e da sedução. E ainda mais: Diotima, como cortesã sagrada, deteve a formação do Filósofo grego do "parto das ideias" no âmbito da erótica. Frisa-se a citação encontrada na introdução desse artigo: "ela que me instruía nas questões de amor" (PLATÃO, 2016, 115f).

Nossa hipótese vai se confirmando quando aferimos que sendo a sacerdotisa/hetaira preceptora de Sócrates, ela tinha regalias por ser uma prostituta. Nota-se que a prostituição era legalizada na Grécia de Péricles (exceto de Sólon), e a mulher de Mantineia sendo cortesã, poderia participar de encontros entre homens, tanto de foro íntimo, quanto de foro filosófico. As pitonisas, do deus efebo Apolo, tinham seu poder religioso e respeitabilidade entre os gregos, entre outras mulheres no imaginário helênico das tragicomédias, a saber:

Un tesoro de mujeres excepcionales nos ha legado la cultura griega. El dolor, la fidelidad, la justicia, la alegría, la belleza, la amistad, la bondad, llenan las páginas de la épica o la tragedia y a las que 'no muerde el diente envidioso del tiempo'. Esos sentimientos ideales los encarnan personajes femeninos que han llegado vivos hasta nuestros días como Ifigenia, Helena, Creusa, Calipso, Fedra, Danae, Antígona, Penélope, Electra, Nausicaa, Dafne, Casandra (LLEDÓ, 2009, p. 01)8.

\footnotetext{
6 "A prostituição sagrada foi, em certo sentido, a manifestação humana de Eros: o verdadeiro corpo pelo qual o homem poderia ter relações sexuais com os deuses. Eros, como as hetaerae, era 'adepto da feitiçaria, do encantamento e da sedução"' (Tradução livre).

7 "Significa 'o que trabalha para o público, artífice, operário manual', demios significando 'do povo' e ourgos, 'trabalhador'. No sentido de "trabalhador para o povo", a palavra foi usada em todo o Peloponeso, com exceção de Esparta, e em muitas partes da Grécia, como sinônimo de um alto magistrado. No pensamento cosmogônico de Platão, o termo designa o artesão divino - causa da alma do mundo - que, sem criar de fato o universo, dá forma a uma matéria desorganizada, imitando as essências eternas, tendo os deuses inferiores, criados por ele, como tarefa a produção dos seres mortais. No pensamento gnóstico, o demiurgo, criador do mundo é distinto do Deus supremo e em geral considerado mau" (DICIONÁRIO DE PORTUGUÊS ON-LINE. Demiurgo. Disponível em $<<$ http://dicionarioportugues.org/pt/demiurgo >> Acesso em março de 2018 (grifos nossos).
}

8 "Um tesouro de mulheres excepcionais nos deixou a cultura grega. A dor, a fidelidade, a justiça, a alegria, a beleza, a amizade, a bondade, preenchem as páginas do épico ou da tragédia e às quais 'o invejoso dente do tempo não morde'. Esses sentimentos ideais são incorporados por personagens femininas que se tornaram vivos até hoje como Ifigênia, Helena, Creusa, Calipso, Fedra, Danae, Antígona, Penélope, Electra, Nausicaa, Daphne, Kassandra" (Tradução livre).

113 Psicanálise \& Barroco em revista | v.17, n. 01 | julho de 2019 
Essas personagens que cumpriam uma função educativa na Grécia, tanto no teatro, quanto na cotidianidade dos helenos, foram consideradas primazes para a formação da Paideia. Quando nos referimos a esse termo, queremos dizer de acordo com Jaeger que:"A Educação participa na vida e no crescimento da sociedade, tanto no seu destino exterior como na sua estruturação interna e no seu desenvolvimento espiritual" (Jaeger , 2010, p. 04). E na dialética platônica, pensando no Banquete, "o principal encanto dramático [...] na maestria das caracterizações individuais" (JAEGER, 2010, p. 725), trouxe-nos a performatividade dos discursos na casa de Agatão rumo a uma educação pela via do amor. Ou pela dialogicidade socrática através do logos (fala, discurso) que discutia eticamente o amor demiurgo pela voz de uma mulher/cortesã. Pois:

\begin{abstract}
Es sorprendente que en boca de esa misteriosa mujer aparezca la primera interpretación y teoría del Eros. El dios del amor llena con sus hazañas toda la literatura griega, pero es precisamente en El banquete, en el que varios hombres intentan definir el origen y sentido del Eros, donde brilla el discurso y la interpretación de la clarividente mujer (LLEDÓ, 2009, p. 01).9
\end{abstract}

Nesse momento, vamos pensar sobre o discurso platônico do Sympósion e sua dívida para com Diotima para entender a dialética do amor pela interpretação clarividente desta sacerdotisa.

\title{
Apontamentos Acerca Da fala De Diotima De Mantineia Em $O$ Banquete, De Platão
}

Devemos levar em consideração que o discurso proposto nesse livro de maturidade de Platão se dá na forma e diálogo. E o que vem a significar esse termo? De acordo com o Larousse (1992, p. 357), "do grego [diálogos]. 1. Conversação entre duas ou mais pessoas. 2. O conteúdo desta conversa; discussão. 3. Obra literária ou científica em forma dialogada".

Devemos perceber que se trata de uma discussão entre duas ou mais pessoas, e é assim que o livro dialogado de Platão irá se colocar - com dialogicidade. Não devemos nos esquecer de que todos os discursos platônicos nos remetem ao logos que vem a ser conceituado como razão ou discurso racional. Mesmo que se fale sobre

\footnotetext{
9 "É surpreendente que na boca dessa mulher misteriosa apareça a primeira interpretação e teoria de Eros. $O$ deus do amor preenche toda a literatura grega com suas façanhas, mas é precisamente em $O$ banquete, em que vários homens tentam definir a origem e o significado de Eros, onde brilha o discurso e a interpretação da mulher clarividente" (Tradução livre).
} 
o Eros, ele será dialogado na perspectiva racional e, principalmente, na dialética, mas objetivando a contemplação através da reflexão conversada.

Como mostra Platão, Sócrates, enquanto articulador da dialética, propõe nos embates de seus diálogos, que tanto o leitor quanto o discípulo encontrem a Aletheia (a Verdade). Essa substância metafísica em Platão será a centrifugação da Forma e das Aparências para se falar em Filosofia - poderíamos chamar essa centrifugação teórica de Doxa e Episteme. O que significa Doxa e episteme para a filosofia de Platão?

Para avançarmos nessa proposta filosófica, de acordo com Dal Maschio (2015), temos o conhecimento (episteme) seguido da Nóiesis (inteligência), e da Diánoia (entendimento, pensamento discursivo) que se farão presentes nas Formas e na matemática. Em contrapartida, haverá a Doxa (opinião, seguida da Pístis crença e da Eikasia (imaginação) que participa do mundo sensível ou dos objetos de experiências. Com isso, cita-se novamente Maschio:

\begin{abstract}
Temos um retrato do conhecimento e da ignorância, mas nada sabemos sobre como podemos alcançar o nível superior da episteme. Chegando a esse ponto, Platão veste-se com suas melhores roupagens místicas, herdadas do orfismo e do pitagorismo. Para começar, porque o acesso à verdade não é resultado de um processo racional, às Formas não se chega através do pensamento, não as 'entendemos' ou 'deduzimos' ou 'aferimos': as Formas 'descobrem-se' ou 'contemplam-se' (MASCHIO, 2015, p. 65).
\end{abstract}

Ou seja, para falar sobre o Amor no âmbito platônico, devemos sempre pontuar que há um mundo de contemplação (o Amor como entidade metafísica no Banquete remete-nos à ideia de que temos parcas lembranças dele, e o mesmo se concretiza em si através do mundo das Ideais, ou do mundo Suprassensível), - o Mundo das Ideias -, e o Mundo Sensível, das experiências; a entidade Amor que será descrita por Sócrates na fala de Diotima, terá essa função precípua e, mais uma, demiúrgica.

A princípio, "O Banquete é, ao mesmo tempo, um dos mais belos e mais simples diálogos platônicos" (SOUZA, 2016, p. 189). Um livro em que a história narrada e o evento de celebração na casa de Agatão são extemporâneos. Tem-se uma estimativa de mais de 20 anos do fato ocorrido na redação do diálogo platônico.

Conta-nos Souza que: "Num jantar em casa de um poeta, que comemora sua vitória no concurso de tragédias, resolvem seus convivas instituir um concurso, oratório desta vez, e em consequência cada um deles faz um discurso de elogio ao Amor, à divindade que presidia aquela jovial heteria" (2016, p. 190). Heteria seria uma 
reunião entre homens, que na Grécia Clássica caracterizava um encontro de pares, de cidadãos em momentos festivos.

Basicamente nessa heteria o Amor será colocado como tema de discussão, ou sendo mais específico, na forma de encômio (louvor ao deus). O eixo axial sobre esse deus, segundo Giovane Reale e Dario Antiseri é:

\begin{abstract}
Entendido como força mediadora entre o sensível e o suprassensível, força que dá asas e eleva, mediante vários graus de beleza, à metaempírica Beleza em si. E visto que para os gregos o Belo coincide com o Bem, ou é de todo modo um aspecto do Bem, assim Eros é força que eleva ao Bem, e a 'erótica' se revela como um caminho alógico que conduz ao Absoluto (REALE; ANTISERI, 2017, p. 152).
\end{abstract}

Deve-se observar que o que está em questão na fala de Sócrates no Banquete refere-se ao Deus Eros, ora belo, ora feio, ou ambos. A visada sempre será no perfil dialético do Belo em si, da beleza em si. Nas palavras de Sócrates em interlocução com Diotima:

\footnotetext{
Não fiques, portanto, forçando o que não é belo a ser feio, nem o que não é bom a ser mau. Assim também o Amor, porque tu mesmo admites que não é bom nem belo, nem por isso vás imaginar que deve ser feio ou mal, mas sim algo que está, dizia ela, entre esses dois extremos (PLATAO, 2016, 154d).
}

A sacerdotisa de Mantineia prepara Sócrates, e seus convivas para dar início ao Amor, esse deus em forma de louvor. Antes de qualquer coisa a hetaira diz que por intermédio do Deus "é que procede não só a arte divinatória, como também a dos sacerdotes que se ocupam de sacrifícios, das iniciações e dos encantamentos, e enfim adivinhação e magia" (PLATÃO, 2016, 156c).

Esse Deus, o Amor, se ocupa com as artes de adivinhação. Ele faz com que os seus servos sejam imantados com os poderes do encantamento e da sedução. Para a sacerdotisa de Mantineia ele era considerado um Deus que propunha suas graças aos iniciados. Sócrates pertencia a um culto órfico, o de Elêusis, uma sociedade secreta entre homens e mulheres no fausto da Grécia Clássica.

De acordo com Loredo (2009, p. 20): “os Mistérios de Elêusis [...] à presença notável de elementos do culto eleusino no texto do Banquete, por exemplo, a distinção entre os Mistérios iniciais e a contemplação perfeita é completa (epotika)". Está-se falando dos mistérios de iniciação, em que Diotima havia proposto ao pai da maiêutica a sua entrada na epotika sob os auspícios dos deuses helênicos (VERNANT, 2006). E qual a função desses deuses? Segundo Jean Pierre Vernant: 
Os deuses gregos não são pessoas, mas Potências. O culto os honra em razão da extrema superioridade da sua condição. Se eles pertencem ao mesmo mundo que os humanos, se eles têm, de certa forma, a mesma origem, eles não participam daquelas deficiências que marcam as criaturas mortais com o selo da negatividade - fragilidade, fadiga, sofrimento, doença, morte - [os deuses] encarnam não o absoluto nem o infinito, mas sim, a plenitude dos valores que são apreciados nesta existência terrena: beleza, força, juventude eterna, fulgor permanente da vida. (VERNANT, 2006, p. 71).

A tônica do mistério de Elêusis referendava a plenitude dos deuses, mesmo que neles houvesse o selo da negatividade, no entanto, de modo absoluto, representam a jovialidade, a beleza e a razão: elementos esses que serão observados no discurso de Diotima. Deve-se frisar que o tônus da Beleza em si e tônus do Amor em si são questionados pela sacerdotisa e hetaira através da fala de Sócrates, voltando ao caráter de demiurgo do Eros. Qual a origem desse amor? Segundo Sócrates, na rememoração da fala da cortesã:

É um tanto longo de explicar, disse ela, todavia, eu direi. Quando nasceu
Afrodite, banqueteavam-se os deuses, e entre os demais se encontrava
também o filho de Prudência, Recurso. Depois que acabaram de jantar, veio
para esmolar do festim a Pobreza, e ficou pela porta. Ora, Recurso,
embriagado com o néctar - pois vinho ainda não havia -, penetrou o jardim
de Zeus e, pesado, adormeceu. Pobreza, então, tramando em sua falta de
recurso engendrar um filho de Recurso, deitou-se ao seu lado e pronto
concebe o Amor. Eis por que ficou companheiro e servo de Afrodite o Amor,
gerado em seu natalício, ao mesmo tempo que por natureza amante do belo,
porque também Afrodite é bela. E por ser filho do Amor de Recurso e de
Pobreza foi esta a condição em que ele ficou. Primeiramente ele é sempre
pobre, e longe está de ser delicado e belo, como a maioria imagina, mas é
duro, seco, descalço e sem lar, sempre por terra e sem forro, deitando-se ao
desabrigo, às portas e nos caminhos, porque tem natureza de sua mãe,
sempre convivendo com a precisão. Segundo o pai, porém, ele é insidioso
com o que é belo e bom, e corajoso, decidido e enérgico, caçador terrível,
sempre a tecer maquinações, ávido de sabedoria e cheio de recursos, a
filosofar por toda a vida, terrível mago, feiticeiro, sofista; e nem imortal é a
sua natureza nem moral, e no mesmo dia ora ele germina e vive, quando
enriquece, ora morre e de novo ressuscita, graças à natureza do pai; e o que
consegue sempre lhe escapa, de modo que nem empobrece o Amor nem
enriquece, assim como também está no meio da sabedoria e da ignorância
(PLATÃO, 2016, 217d).

Já se sabe a partir desse momento que o Deus Amor ascende de uma mãe podre e de um pai de recursos, ou seja: a gênese do Eros estará entre a sabedoria e a ignorância, entre a necessidade de buscar algo e dele fazer recurso para alcançar, seja pelos encantamentos, seja pela sedução. Todo o discurso de Diotima de Mantineia, reapresentado por Sócrates, descaracteriza a ideia que se tem sobre esse deus, colocando-o na feição de um demiurgo. Ele nem é belo, nem feio, apenas é um médium entre os homens e os deuses. 
Segundo Reali: "Amor não é nem belo nem bom, mas é sede de beleza e de bondade. Amor não é, portanto, um deus (Deus é só e sempre belo e bom), mas sequer é homem. Não é mortal nem imortal: é um desses seres daimoníacos 'intermediários' entre homem e Deus” (REALI, 2017, p.152-153). Sendo o amor um intermediário entre os deuses e os homens, esse "eros, concebido [...] é ao mesmo tempo o impulso para a verdadeira realização essencial da natureza humana, e portanto um impulso cultural no mais profundo sentido da palavra" (JAEGER, 2010, p. 739).

Sobre o Amor, Reali e Antirese apontam:

Amor é, portanto, filo-sofo, no sentido mais carregado do termo. A sophia, isto é, a sapiência, é possuída somente por Deus, a ignorância é própria daquele que está totalmente alienado da sapiência; ao contrário, a filosofia é própria de quem não é nem ignorante nem sapiente, não tem o saber, mas a ele aspira, está a procura, e aquilo que encontra lhe escapa e deve procurá-lo além (REALE; ANTIRESE, 2017, p. 153).

Na afirmação acima, como ficará a educação ou paideia do 'erotismo' ou do Amor como demiurgo?

Nas relações entre os homens de Atenas havia a prevalência da pederastia. Um homem mais velho (erastes) iniciava seu discípulo na arte do saber. Esse jovem era chamado de erômenos. Tal relação mantinha a característica da dialética no sentido de haver uma sensatez entre os politikos na Academia platônica - local privilegiado dos amantes aprendizes. Diotima falará sobre isso ao se referir às mutabilidades do amor, pois:

\footnotetext{
em geral, todo esse desejo do que é bom e de ser feliz, eis o que é 'o supremo e insidioso amor, para todo homem', no entanto, enquanto uns, porque se voltam para ele por vários caminhos, ou pela riqueza ou pelo amor à ginástica ou à sabedoria, nem se diz que amam nem que são amantes; outros ao contrário, procedendo e empenhando-se numa só forma, detêm o nome do todo, de amor, de amar e de amantes (PLATÃO, 2016, 203c).
}

A relação entre amante e amado é um exercício filosófico no sentido de promover a sabedoria. Os erastes e os erômenos mantinham um diálogo de amor ao saber. O que Diotima diz é a importância desse vínculo na manutenção da Paideia grega e da cultura do V século a. C.

Sócrates, com a parturição de ideias, retoma o conceito de mundo sensível e inteligível. Ora, para parir ideias pela cavilha do Eros, requerer-se-á que o amante e o amado se detenham no saber que nos é mostrado, parcialmente, no nosso Mundo Sensível, pela ótica da Doxa. A episteme ou a Forma detém uma contemplação que 
no parto das ideias os amantes discutirão e se lembrarão - reminiscências - da origem primeira das Ideias pelo Amor.

Nosso mundo, segundo Platão, é uma sombra nebulosa regida pela experiência e que guarda através do diálogo e da metodologia da maiêutica a possiblidade de parir/conceber/mostrar/lembrar das Ideias esquecidas ou evanescidas. Segundo Emilio Lledó:

\begin{abstract}
El Eros nos hace salir de nosotros mismos, nos arranca de la soledad y nos inserta en un mundo distinto y perenne donde la efímera individualidad se alza hasta la verdad y la belleza 'con lo que todo bueno está emparentado'. Ese ascenso es una muestra de cómo en el desvelo amoroso, sometido a la propia estructura corporal, brota la esperanza que es, en el río del amor y la memoria, la forma humana de eternidad. Todo lo otro que ha montado el gran engaño de la ignorancia es pura miseria y, en el peor de los casos, pura perversión lastimosa del inabarcable territorio del amor. 'En él sí que merece la pena vivir', dijo la mujer de Mantinea.10 (LLEDÓ,2009, p 05)
\end{abstract}

A tentativa da hetaira em falar sobre o Amor é aquela que nos faz pensar ser o Eros do filósofo regido pela ignorância e pela sabedoria concomitantemente, pois "ela aproxima eros da opinião verdadeira, conceito fundamental para a concepção platônica de educação. [...] filosofar é estar à procura de algo. Eros e filosofia têm como condições naturais o desejo ou a falta de saber" (PAVIANI, 2008, p. 86).

\title{
CONSIDERAÇÕES FINAIS
}

Todo deslocamento textual no sentido de lhe dar uma hermenêutica requer sacrifícios e atenção à obra na qual se debruça. Nesse sentido, o Banquete platônico foi o códice pesquisado e voltado às relações do amor discutido/dialogado por uma hetaira.

Essa mulher, sacerdotisa e prostituta, foi quem ensinou a Sócrates a arte do amor. Tal amor que no diálogo platônico nasceria de pais distintos, na festa de Afrodite, de um pai astuto, e de uma mãe pobre. Através desse vínculo o Amor tornouse um demiurgo, - um médium entre os homens (mortais) e os deuses. Uma missão alvissareira se não fosse o espírito precário do amor.

\footnotetext{
10 "Eros nos faz sair de nós mesmos, nos tira da solidão e nos insere em um mundo diferente e perene, onde a individualidade efêmera se eleva à verdade e à beleza 'com as quais todo bem está relacionado'. Essa ascensão é um sinal de como, na insônia amorosa, submetida à própria estrutura do corpo, surge a esperança que é, no rio do amor e da memória, a forma humana da eternidade. Tudo o mais que tem montado o grande engano da ignorância é pura miséria e, no pior dos casos, pura perversão lamentável do território ilimitado do amor. 'Vale a pena viver', disse a mulher Mantinea” (Tradução livre).
}

119 Psicanálise \& Barroco em revista | v.17, n. 01 | julho de 2019 
Quando falamos de precário nos reportamos a faltoso. No encômio ao Deus, na versão socrática, o filósofo aparece como a encarnação do daimon descrito pela sacerdotisa. Podemos dizer que a relação Diotima-Sócrates enveredou pelo amor/contemplação que teve uma função filosófica, a saber, uma contemplação intelectual sobre o belo, sobre o Eros: o amor como nascido do discurso socrático visando um grau elevado entre os amantes numa dimensão espiritual.

A presença da mulher no encômio ao Deus Eros na casa de Agatão, chamounos atenção por se tratar de uma sociedade misógina. Podemos dizer que sendo sacerdotisa, com seus encantos e presságios, Diotima, através da leitura de Sócrates, não somente se valeu desse artifício de sacerdotisa, como também do status de ser uma prostituta.

Na Grécia Clássica, na época de Péricles, a arte de se prostituir era louvada, a hetaira não estava no Oîkos, mas estava nas praças, nos banquetes, nas ruas e na academia grega. Para ser uma mulher hetaira fazia-se necessário o conhecimento dos textos antigos e iniciatórios e dos códices da aristocracia helênica. À mulher comum do oîkos restava a casa, os afazeres domésticos e o cuidar dos filhos, não havendo permissão para entrar nos recintos masculinos como faziam as cortesãs (ROBERTS, 1998).

O que nos provocou no texto platônico foi à tônica da Diotima sacerdotisa, detentora de encantos, e de Sócrates, igualmente considerado encantador pelas suas palavras e discurso (um Sileno, nas palavras de Alcebíades).

Conclui-se que o diálogo sobre o amor é um intermezzo entre os homens e os deuses. Eros, o demiurgo, propunha, nas palavras de Sócrates, ser aquela entidade que livraria o filósofo da ignorância, pois ele era faltoso, e o colocaria com o absoluto, com o saber, pois ele era recurso (expediente). A falta era sua mãe, e o recurso seu pai: com eles o "amigo da sabedoria" poderia conseguir sair das aparências através do ato dialogado e da dialética que paria. 


\section{REFERÊNCIAS}

CAMPOS, K. R. Pólis vs. Oikos: a investigação do papel feminino no drama grego. Mimio. Faculdade de Ciências e Letras - Unesp/Araraquara, 2015. Disponível em $<<$ https://repositorio.unesp.br/bitstream/handle/11449/139095/000865162.pdf?sequence=1 $>>$ Acesso em Agosto de 2017.

DICIONÁRIO DE PORTUGUÊS ON-LINE. Demiurgo. Disponível em $<<$ http://dicionarioportugues.org/pt/demiurgo >> Acesso em março de 2019.

DICIONÁRIO ETIMOLÓGICO. [s.d.]. Verbete P. Disponível em

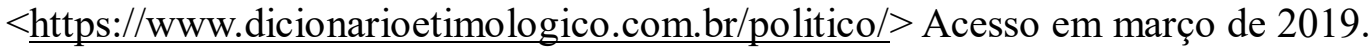

FLORENZANO, M. B. B. Pólis e oîkos: o público e o privado na Grécia Antiga. Publicado nos Anais do I Simpósio Regional de História Antiga, Rondonópolis, M.T (LAPECA). 2010. Disponível em $<<$ http://labeca.mae.usp.br/media/pdf/florenzano_polis_e oikos.pdf $>>$ Acesso em agosto de 2017.

JAEGER, W. Paideia: a formação do homem grego. 5 ed. Tradução Artur Parreira. São Paulo: Martins Fontes, 2010.

LAROUSSE. Dicionário da língua portuguesa. São Paulo: Nova Cultural Ltda, 1992.

LIMA, N. R. Gênero - Curso de especialização em gênero e diversidade na escola. Alagoas: UFAL, [s.d].

LLEDÓ, E. El Eros de Diotima. El País: 2009. Disponível em $<<$ https://elpais.com/diario/2009/10/04/eps/1254637623 850215.html >> Acesso em Agosto de 2017.

LOREDO, C. R. Eros e a iniciação: Um estudo sobre as relações entre a paidéia platônica e os antigos cultos gregos de Mistério a partir do Banquete. Mimio. Departamento de Filosofia (Mestrado). FAJE: Faculdade Jesuíta de Filosofia e Teologia. 2009. Disponível em $<<$ http://www.faculdadejesuita.edu.br/documentos/111213-WNJlJlzPuYcb.pdf $\gg>$ Acesso em Agosto de 2017.

MARDONES, M.A.H. De la hetaerea a la ramera: el viaje alegórico de la prostituta hacia la modernidade latino-americana. Dissertação de mestrado. Stanford University, 2010. Disponível em:

https://stacks.stanford.edu/file/druid:dw170ch0322/Hernandez\%20Dissertationaugmented.pdf . Acesso em dezembro de 2018.

MASCHIO, E. A. D. Platão - A verdade está em outro lugar. São Paulo: Salvat, 2015.

NUNES, P. S. História da Cultura e das Artes. 11 ed. Lisboa: Lisboa Editora, 2005.

PAVIANI, J. Platão \& a educação. Belo Horizonte: Autêntica, 2008.

PLATÃO. Apologia de Sócrates. Tradução de Maura Iglesias. São Paulo: Nova Cultural, 1999. PLATÃO. Diálogos. Tradução de José Cavalcante de Souza. Rio de Janeiro: Globo, 1964.

PLATÃO. O Banquete. Tradução, posfácio e notas de José Cavalcante de Souza. São Paulo: Editora 34, 2016.

REALI, G; ANTISERI, D. Filosofia - Antiguidade e Idade Média. São Paulo: Paulus, 2017, volume 1.

ROBERTS, N. As prostitutas na história. Rio de Janeiro: Record, 1998. 
O Discurso Sobre O Amor No Banquete, De Platão, E A Presença De Diotima De Mantineia: Mulher/Sacerdotisa/Hetaira

SOUZA, J. C. As grandes linhas da estrutura do Banquete. In.: PLATÃO. O Banquete. São Paulo: Editora 34, 2016.

TEIXEIRA, E. F. B. A Educação do homem segundo Platão. São Paulo: Paulus, 1999.

VERNANT, J. P. Mito e Religião na Grécia Antiga. Tradução Joana Melo. São Paulo: Martins Fontes, 2006. 


\title{
The Discourse On The Love In The Banquet, Of Plato, And The Presence Of Diotima De Mantineia: WOMAN/PRIESTESS/HetaIRA
}

\begin{abstract}
This article is about the discourse of Diotima of Mantineia in Plato's Banquet (2016). The speech of the priestess and hetaira (prostitute) was used through the speech of Socrates to deal with Love as a demiurgic entity. In the Platonic dialectic we observe that the Eros is an intermediary between men and the gods: son born of a poor mother and a resourceful father. The hypothetical question raised through the text/fabric of the aristocrat Plato was, even in a discursive instance, entered by a woman in a male enclosure to make love to the Platonic dialogue. It is noteworthy that Diotima of Mantineia was a priestess and hetaira (courtesan), and that, for this reason, her presence was tolerated among the guests of the Banquet, even if, in a domain dominated by discursiveness. We conclude that the presence of Diotima of Mantineia brought to the philosophical plot of the Banquet the opportunity to reaffirm the Platonic metaphysics of the Forms (world of Ideas) and of the experience (sensible world) that affect the formation of the philosopher being, in turn, debtor of the Episteme born of Doxa to become an authentic lover of wisdom.
\end{abstract}

KEYWORDS: Banquet; Diotima of Mantineia; Hetaira; Eros. 


\section{Le Discours Sur L’amour Au Banquet De Plato Et La Présence De Diotima De Mantineia: FEMme/PrÊtREsSe/HetAIRA}

\section{RÉSUMÉ}

Cet article porte sur le discours de Diotima de Mantinée au banquet de Platon (2016). Le discours de la prêtresse et de l'hetaira (prostituée) a été utilisé dans le discours de Socrate pour traiter de l'amour en tant qu'entité démiurgique. Dans la dialectique platonicienne, nous constatons que l'Éros est un intermédiaire entre I'homme et les dieux: fils né d'une mère pauvre et d'un père plein de ressources. La question hypothétique soulevée à travers le texte/le tissu de l'aristocrate Platon était l'entrée, même discursive, d'une femme dans un enclos masculin pour faire l'amour au dialogue platonicien. II est à noter que Diotima de Mantineia était une prêtresse et une hetaira (courtisane) et que, pour cette raison, sa présence était tolérée parmi les invités du banquet, même si, dans un domaine dominé par le discursivité. Nous concluons que la présence de Diotima de Mantinée a apporté au complot philosophique du banquet l'occasion de réaffirmer la métaphysique platonicienne des formes (monde des idées) et de l'expérience (monde sensible) qui affecte la formation du philosophe, à son tour débiteur. de l'Episteme né de Doxa d'être un authentique amoureux de la sagesse.

MOTS-CLÉS : Banquet; Diotima de Mantinée; Hetaira; Eros. 
Recebido em: 17-04-2019

Aprovado em: 02-06-2019

(C) 2019 Psicanálise \& Barroco em revista

http://www.seer.unirio.br/index.php/psicanalise-barroco/index

revista@psicanaliseebarroco.pro.br

Programa de Pós-Graduação em Memória Social — UNIRIO.

Memória, Subjetividade e Criação.

http://www.memoriasocial.pro.br/proposta-area.php

125 Psicanálise \& Barroco em revista | v.17, n. 01 | julho de 2019 